\title{
Illegal Fishing: In the Eyes of Filipino Fishermen
}

\author{
Angelita B. Alvarico ${ }^{1}$, Jose F. Cuevas Jr. ${ }^{2} \&$ Julius B. Dinsay ${ }^{3}$ \\ 1,2 Misamis University, Ozamiz City, Philippines. Email: criminology@mu.edu.ph \\ ${ }^{3}$ Directorate for Logistics, Plans and Programs Division, Philippine National Police
}

DOI: http://doi.org/10.46382/MJBAS.2021.5108

Copyright: $\odot 2021$ Angelita B. Alvarico et al. This is an open access article distributed under the terms of the Creative Commons Attribution License, which permits unrestricted use, distribution, and reproduction in any medium, provided the original author and source are credited.

Illegal fishing is a common practice among Filipino fishermen, particularly in province areas. Under the Philippines' law, fishing without authorization and cause damage to the marine ecosystem is considered illegal and punishable. This qualitative study was conducted to unfold fishermen's stories in illegal fishing, particularly in the coastal areas of Misamis Occidental. Snowball sampling was utilized to identify the 8 participants who engaged in illegal fishing for at least five years. This study used Moustakas' transcendental phenomenology to analyze the data and come up with meaningful themes. Four meaningful themes emerged from their stories; acquired local practice, economic abundance, anxiety and fear, and be law-abiding and upright. It revealed that fishermen were influenced by their family, peers, and community to commit illegal fishing activities. They spur to shift their traditional fishing methods due to their family's needs, particularly the education and the unexpected hospitalization among family members. Based on the study, it is recommended that the government strengthen its information campaign against illegal fishing and provide additional income to sustain the fishermen's essential needs.

Keywords: Abundance, Community practice, Illegal fishing, Anxiety and Fear.

\section{Introduction}

Fishing is among the oldest method of living, wherein the people living in the coastal areas depend on the abundance of aquatic resources. Until today, millions of people rely on marine fisheries for food and livelihood. Unfortunately, many fishermen engaged in a fast and more profitable way of fishing through illegal methods because of the high demand. Illegal fishing has different methods, but it has a devastating effect on the depletion of fish stock (Afoakwah, Osei, \& Effah, 2018; Gillam \& Charles, 2018; Hilborn, 2011).

The latest estimate is nearly 80 percent of global fish stock has been over-exploited or depleted. According to marine scientists, overfishing threatens not only aquatic food supply but also affect the entire food webs and ecosystems (Arias, \& Pressey, 2016; Pala, Zhang, Zhuang, \& Allen, 2018; Purcell, Mercier, Conand, Hamel, Toral-Granda, Lovatelli, \& Uthicke, 2013). Like other countries, illegal fishing in the Philippines remains one of the greatest threats to marine ecosystems. The Philippines is an archipelago type of country wherein it is surrounded by a body of water (Quiazon, Santos, \& Yoshinaga, 2013). This structure provides extra challenges for law enforcement authorities to control and prevent illegal fishing due to several exit points in different coastal areas. Illegal fishing is a wide range of marine exploitation committed by small-scale and commercial fishing on the high seas and areas under national and local jurisdiction (Daliri, Kamrani, Jentoft, \& Paighambari, 2016; Pomeroy, Garces, Pido, \& Silvestre, 2010; Pomeroy, Nguyen, \& Thong, 2009). The existing illegal fishing continues to establish stiffer law, the Republic Act 10654 known as An Act to Prevent, Deter and Eliminate Illegal, Unreported and Unregulated Fishing amending the Republic Act No. 8550, otherwise known as The Philippine Fisheries Code of 1998. The law is not only intended to punish the fishermen engaged in illegal fishing, but it heightens the monitoring, control, and surveillance system through establishing strong coordination between the 
local and national government, including the participation of the private sectors. It emphasizes the reciprocal responsibilities of controlling and preventing illegal fishing in their respective areas (Gomez, 2020; Acosta, 2019).

Despite the action done by the government and community, illegal fishing continues to exist today. Although there are several studies focuses on illegal fishing. However, many of them focused more on industry and large commercial fishing. No in-depth studies are focusing on local and small-scale fishing. Hence, this study was conducted and aimed to explore local fishermen's stories engaged in illegal fishing in the coastal areas of Misamis Occidental.

\section{Methods and Materials}

The study used a qualitative research design, particularly the phenomenological approach. In this approach, the researchers were challenged to describe something as they are, to understand meanings and essences in the lights of intuition and self-reflection (Moustakas, 1994; Trace, 2017). This research design was suited to explore and uncover Filipino fishermen's stories living in the coastal areas of Misamis Occidental. It was conducted in the province of Misamis Occidental northern part of Mindanao, specifically, in the coastal areas of the Tangub City, Ozamiz City, Oroquieta City, and in the 10 municipalities, namely, Bonifacio, Clarin, Tudela, Sinacaban, Jimenez, Panaon, Aloran, Lopez Jaena, Plaridel and Baliangao. The study was voluntarily participated by eight fishermen engaged in illegal fishing for at least five years. The participants were chosen through the snowball method and utilized interview guide questions to collect stories and experiences. All questions were first piloted before the actual gathering of data. This process ensured that the questions were suitable to solicit relevant information from the participants. In analyzing the data, the researchers utilized two methods-first, NVivo software to generate the codes-Second, before the themes are applied, the researchers sought the assistance of an external researcher who is an expert in the process of phenomenological analysis to check and validate the developed themes emerged from the statement of the participants.

\section{Results and Discussions}

The eight fishermen who participated in the study were between 23 to 44 years old. All of them have at least four to seven dependents and breadwinners in their own families. They have all at least five to eighteen years of fishing experienced. The participants rely solely on this means of livelihood and engaged in illegal fishing in the later years. Some are involved in illegal fishing for five to 10 years, with an average income of approximately more than 10,000 pesos per catch. These fishermen were caught in the act of doing illegal fishing by maritime police in the waters of Panguil bay and Iligan bay violating the provision of section 86 (Unauthorized Fishing), section 93 (Use of fine mesh net3), and section 95 (Use of active gear in municipal waters) of Republic Act of 8550, "the Philippine Fisheries Code of 1998" as amended by the Republic Act of 10654 (Gomez, 2020). Four themes emerged from the eight fishermen's stories: acquired local practice, economic abundance, anxiety/fear, be law-abiding and upright.

\subsection{Acquired Local Practice}

Fishermen who engaged in illegal fishing acquired this fishing method from their family, peers, and community. It dramatically showed how the people in the surrounding affect one's life. The illegal practices by friends and family 
can influence the behavior and action of each individual. Based on gathered information, Participant 1 resorted to illegal fishing since it was practiced and taught by their fathers, who were also fishermen. He remembered his father's teaching and stated that "It was my father who taught me and made me develop the interest to engage in illegal fishing."

On the other hand, Participant 2 was influenced by his friend and co-fisher folk to engaged in the illegal fishing method. They encourage him to engage in such activity because it was already common among them, even though they knew it was illegal. According to him, "It was my friend, also a fisherman, who taught me this kind of fishing method." That encouragement builds his confidence to engage in illegal fishing activity.

Like participants 2 and 3, participant 7 engaged in illegal fishing through the influence of his co-fisherman.

"Since we do fishing together, I immediately engaged in this means of fishing. Because it is very convenient and profitable than the usual means of fishing (P7)."

Local practice is commonly known as community practice, which is based on the community members' learning process. For them, illegal fishing becomes their social norm as the fishing community. According to Lave and Wenger, as Cain (2018) cited and Rodrigue (2017), the learning process or theory describes the absorption of knowledge or skills through environmental influences. It can be learned through interaction and participation in certain activities. The acquired illegal practices among fishermen resulted from a shared interest in the specific activities, which led to the acceptance of methods among community members. However, the local practice is customary ways of any community in general, which has a positive effect. However, there were also negative consequences once prohibited acts become accepted norms. It is no longer viewed as a crime or immoral act since it can provide a valuable and usable end. (Chapsos, Koning, \& Noortmann, M. 2019; Sozer, 2008).

\subsection{Economic Abundance}

A common theme has emerged from their shared answered on why they engaged in illegal fishing. They engaged in this illegal method because of profitable income - economic abundance. All participants have their fair share of experience in fishing, yet they are barely surviving. Their income is just enough for their day-to-day subsistence, considering the number of dependents they are supporting. Thus, after all the years of fishing, they resorted to illegal fishing with a common reason: to acquire or gain more profit.

Participant 1 mentioned that being a fisherman for almost ten years was his only way of living. He has no other source of income, and he needed to gain more income. This led him to engage in illegal fishing activity. "It was my only way of living, and I earn more profit than the normal fishing method (P1)." Participants 2 and 3 gave the same responses. "It is more profitable than traditional fishing methods." Considering the risk that these fishermen have to take, they thought of the earnings they gained from illegal fishing methods. Moreover, Participant 4 also emphasized that he had never earned much in doing normal fishing. Hence, he resorted to illegal fishing. "I never earned this much for the past years of doing normal fishing." Participant 6 stated that doing this act gives him the ability to support his family on their day-to-day expenses. The aid that illegal fishing helps him to do more and help his family more. "I can help my family in our daily expenditure. I have to feed my family. I don't want my 
family to be hungry". Participants 7 and 8 that their daily needs and other than food like medication were being provided by gaining more income. The statement they shared justifies that they need to engage in illegal fishing to double their catch and earn more. "I need to feed my family as well as to provide for my mother's medication."

It cannot be denied that these fishermen were driven primarily by the monetary benefits they can acquire out from illegal fishing activities. Under the concept of economic crimes, people such as the fishermen were attracted to illegal ways and profitable outcomes (Griffiths, \& Auer, 2019; Pfeiffer \& Gratz, 2016). It is a rational choice of a person to weigh his action based on good and bad consequences. Most of the time, bad overpowers the good due to the equivalent monetary benefit. Fishermen viewed traditional fishing as a low profitable method. They were motivated to commit such illegal methods to sustain their family's needs, particularly for their children's education and support for sudden hospitalization (Burdett, 2010; Ganter, 2009; Nemoto, 2002).

\subsection{Anxiety and Fear}

Being caught in the act of doing illegal fishing made the participants feel anxious and fearful. These feelings give a general impression that leads to the third theme's formulation: anxiety and fear. Participants 1,2 , and 3 felt nervous because they knew that what they were doing was illegal and gave them a guilt feeling, which resulted in anxiety and fear of the possible penalty they might receive. It was evident in their answers:

"I was in a hurry and nervous at that time. The maritime police apprehended us immediately and gave us details that the said method we used in fishing was illegal (P1)."

"We were nervous when the maritime police arrived and arrested us (P2)."

"I was shocked when the Maritime Police approached me. I was stuttering while answering their questions. I did not understand what I was feeling. I can no longer comprehend what the maritime police were saying at that time. All I know was I got caught doing illegal fishing (P3)."

Participant 4 was also shock and nervous. The situation blew the state of consciousness to the extent that he did not know what had happened. He stressed his answer during the interview.

"We were caught in the act and were not able to escape. The maritime police approached us immediately and apprehended us, informing us that our method of fishing was illegal (P4)."

Participant 7 and participant 8 stated accordingly. They said that they were afraid of thinking that what they were doing was illegal. The maritime police apprehended them and gave them the details of the cause of their apprehension, for they were caught in the act of doing illegal fishing.

"We were very afraid. I thought it is going to be the end of us. When they caught us with what we are doing, they immediately told us and gave details that the said fishing method we were using was illegal (P7)."

"I was scared of what might happen. All I could think about was the welfare of my family. I was worried and felt my blood was draining from my face (P8)." 
Fear is one of the primary emotions common to human and animal species (De Waal, 2019). It is almost linked to a survival instinct, an unpleasant alarm bell that constantly rings to a person's reaction to fight or flight the situation. Further, fear is a precaution that allows human beings to define their limits (Cavaliere, 2017). Also, fear is healthy to the extent that it limits individuals, prevents them from going to the brink; otherwise, it risks negatively invading their perception of the world and the things that happen. In this case, fear becomes limiting and does not allow them to act and move forward, to evolve (Gatti, 2018).

\subsection{Be Law-abiding and Upright}

The last theme gives details on how law enforcement agencies, particularly the maritime police, played an essential role in implementing policy under RA 8550 as amended by RA 10654. Being caught by the authority was their turning point for the fishermen to stop the illegal fishing method. Their experiences served as an eye-opener for all apprehended participants. The severity of the punishment and the law enforcement agency's firm implementation urged the participants and other fishermen to stop and revert to traditional but legal methods of fishing. These were the shared statement of the participants:

"When the maritime police apprehended me, I instantly decided to stop the illegal fishing for the sake of my family (P1)."

"When we are arrested, the maritime police explained to us that there is another safe and lawful fishing method. For that, we decided to stop and go back to a normal fishing method (P2)."

"When I got caught by the Maritime Police, it was a wake-up call for me to stop and start doing things right before its too late (P3)."

"It was the police who encourage us not to do it again, for it was punishable by law because I don't want to go to jail (P4)."

Their realization and sense of responsibility led P7 and 8 to stop doing illegal fishing. Their responsibility to provide for their family's needs urged them to stop and find other legal means of fishing. They tend to go back to traditional fishing, which was safe and secure from any law violation.

"I was thinking of my family. The moment we get caught, I was scared not only for myself but for my family. Who will feed them if I go to jail and my children are still young? I decided to stop and make things right this time, though it was still tempting to go back to my old ways thinking about my family, I cannot risk it (P5)."

"We decided that it is best to earn and feed our family using clean hands. What we did might have saved us from being hungry, but the risk and what might happen again is not worth it. It will just push us to danger and especially our family, so we chose to make it right this time (P7)."

It was identified that preserving self-identity or social identity, family or counseling intervention, and social degradation are among the common reasons for crime desistance (Giordano, Cernkovich, \& Rudolph, 2002; Paternoster, \& Bushway, S. 2009). Accordingly, the severity of punishment has no assurance of desisting from 
criminal behaviors. Although their realization was upshot after their arrest, the truth is that their family is the main reason for the fishermen to decide to do the right fishing methods. They decided to be law-abiding and upright not for their fear of imprisonment but their family's welfare. They realized the importance of their family, particularly their children's futures (Burdett, 2010; Plesnicar, 2015; Giordano et al., 2002).

\section{Conclusion and Recommendation}

The findings show that illegal fishing in Misamis Occidental resulted from family, peers, and community influences. Thus, their experience pushes them to continue to gain more profitable income. The traditional fishing method can only sustain their day-to-day needs, but it cannot support their family's other essential needs, such as education and hospitalization. As a result, fishermen have no choice and switch their method to more profitable but punishable acts. Engaging in illegal fishing provides them almost double their catches. However, they become cautious, which resulted in their psychological distress. The participants felt anxious and fearful after the law enforcers apprehended them. Their family's welfare persuaded the fishermen's decision to stop and return to conventional but legal fishing methods.

Hence, it is recommended that the Bureau of Fisheries and Aquatic Resources, City/Municipal Agricultures Office, Philippines National Police-Maritime Group, Local Government Unit, and other concern offices work hand-in-hand to address the problems on illegal fishing through intensifying information campaign on the fishing methods and governing laws. Local government units should introduce and encourage fishermen and their families to engage in other activities that would provide them with additional income to sustain their day-to-day needs. Build a healthy collaborative approach between fishermen and law enforcement agencies to guard their municipal waters for any possible illegal fishing activities. Further studies relating to the same topic must be conducted to develop a more systematic approach for the fishermen to be more empowered and knowledgeable about the utilization, management, development, conservation, and protection of aquatic resources.

\section{References}

[1] Acosta, P. (2019). Purchase of an endangered species. The Manila Times, A4.

[2] Afoakwah, R., Osei, M. B. D., \& Effah, E. (2018). A guide on illegal fishing activities in Ghana. USAID/Ghana Sustainable Fisheries Management Project. Narragansett, RI: Coastal Resources Center, Graduate School of Oceanography, University of Rhode Island. Prepared by the University of Cape Coast, Ghana. GH2014_SCI048_UCC, 64.

[3] Arias, A., \& Pressey, R. L. (2016). Combatting illegal, unreported, and unregulated fishing with information: A case of probable illegal fishing in the tropical eastern pacific. Frontiers in Marine Science, doi:http://dx.doi.org/10.3389/fmars.2016.00013.

[4] Burdett, C. M. O. (2010). The use of traceability to combat the economic drivers of illegal, unreported and unregulated fishing: A case study (Order No. MR64614). Available from ProQuest Central. (745593081). Retrieved from https://search.proquest.com/docview/745593081?accountid=149218. 
Mediterranean Journal of Basic and Applied Sciences (MJBAS)

Volume 5, Issue 1, Pages 104-111, January-March 2021

[5] Chapsos, I., Koning, J., \& Noortmann, M. (2019). Involving local fishing communities in policy making: Addressing Illegal fishing in Indonesia. Marine Policy, 109, 103708. Retrieved on June 29, 2020 from https://bit.ly/3ibJGJO.

[6] Daliri, M., Kamrani, E., Jentoft, S., \& Paighambari, S. Y. (2016). Why is illegal fishing occurring in the Persian Gulf? A case study from the Hormozgan province of Iran. Ocean \& coastal management, 120, 127-134. Retrieved on June 30, 2020 from https://bit.ly/2BV9qJO.

[7] Ganter, S. (2009). Modelling the grand banks commercial fishing fleet: Fleet structure, fishing performance and economic viability (Order No. MR58194). Available from ProQuest Central. (89239876). Retrieved from https://search.proquest.com/docview/89239876?accountid=149218.

[8] Gillam, C., \& Charles, A. (2018). Fishers in a Brazilian Shantytown: Relational wellbeing supports recovery from environmental disaster. Marine Policy, 89, 77-84. Retrieved on March 05, 2020 from https://bit.ly/2Y3HkF3.

[9] Giordano, P. C., Cernkovich, S. A., \& Rudolph, J. L. (2002). Gender, crime, and desistance: Toward a theory of cognitive transformation. American journal of sociology, 107(4), 990-1064. . Retrieved on June 30, 2020 from https://bit.ly/3dPxD1n.

[10] Gomez, E. J. (2020). BFAR urged to fast track fishing vessel trackers. The Manila Times, A7. Retrieved on June 30, 2020 from https://bit.ly/31Cgfe0.

[11] Griffiths, M. D., \& Auer, M. (2019). Becoming hooked? Angling, gambling, and "fishing addiction". Archives of Behavioral Addictions, 1(1). Retrieved on March 07, 2020 from https://bit.ly/3cYi86T.

[12] Hilborn, R. (2011). Overfishing: What Everyone Needs to Know®. Oxford University Press.

[13] Nemoto, K. (2002). Modeling the impacts of area closures on the hawaii longline fishery: A spatial -temporal economic model incorporating fish movement (Order No. 3070717). Available from ProQuest Central. (305532256). Retrieved from https://search.proquest.com/docview/305532256?accountid=149218.

[14] Pala, A., Zhang, J., Zhuang, J., \& Allen, N. (2018). Behavior analysis of illegal fishing in the gulf of mexico. Journal of Homeland Security and Emergency Management, 15(1).

[15] Paternoster, R., \& Bushway, S. (2009). DESISTANCE and the "feared self": toward an identity theory of criminal desistance. Journal of Criminal Law \& Criminology, 99(4), 1103-1156. Retrieved from https://search.proquest.com/docview/218442739?accountid=149218.

[16] Pfeiffer, L., \& Gratz, T. (2016). The effect of rights-based fisheries management on risk taking and fishing safety. Proceedings of the National Academy of Sciences, 113(10), 2615-2620. Retrieved on March 05, 2020 from https://bit.ly/3hp2yVp.

[17] Plesnicar, M. M. (2015). Why do people stop Offending? recent theories on desistance and their value in practical approaches to $\mathrm{O}$ ffenders. Zbornik Znanstvenih Razprav, 75, 191-212. Retrieved from https://search.proquest.com/docview/1850342617?accountid=149218. 
[18] Pomeroy, R., Garces, L., Pido, M., \& Silvestre, G. (2010). Ecosystem-based fisheries management in small-scale tropical marine fisheries: emerging models of governance arrangements in the Philippines. Marine Policy, 34(2), 298-308.

[19] Pomeroy, R., Nguyen, K. A. T., \& Thong, H. X. (2009). Small-scale marine fisheries policy in Vietnam. Marine Policy, 33(2), 419-428.

[20] Purcell, S. W., Mercier, A., Conand, C., Hamel, J. F., Toral-Granda, M. V., Lovatelli, A., \& Uthicke, S. (2013). Sea cucumber fisheries: global analysis of stocks, management measures and drivers of overfishing. Fish and fisheries, 14(1), 34-59.

[21] Quiazon, K. M. A., Santos, M. D., \& Yoshinaga, T. (2013). Anisakis species (Nematoda: Anisakidae) of Dwarf Sperm Whale Kogia sima (Owen, 1866) stranded off the Pacific coast of southern Philippine archipelago. Veterinary parasitology, 197(1-2), 221-230.

[22] Trace, C. B. (2017). Phenomenology, experience, and the essence of documents as objects. Retrieved on March 01, 2020 from https://bit.ly/2UJFneN. 